\title{
Lichen Zonation on Coastal Rocks in Gwaii Haanas National Park Reserve, Haida Gwaii (Queen Charlotte Islands), British Columbia
}

\author{
IRWIN M. BRODO ${ }^{1}$ and NORM A. SLOAN ${ }^{2}$ \\ ${ }^{1}$ Canadian Museum of Nature, P. O. Box 3443 Station D, Ottawa, Ontario K1P 6P4 Canada \\ ${ }^{2}$ Parks Canada, Gwaii Haanas National Park Reserve and Haida Heritage Site, P. O. Box 37, Queen Charlotte City, British \\ Columbia V0T 1S0 Canada
}

Brodo, Irwin M., and Norm A. Sloan. 2004. Lichen zonation on coastal rocks in Gwaii Haanas National Park Reserve, Haida Gwaii (Queen Charlotte Islands), British Columbia. Canadian Field-Naturalist 118(3): 405-424.

The occurrence of 43 marine lichen species on intertidal rocky shores of southern Haida Gwaii (Queen Charlotte Islands), British Columbia is described and related particularly to elevation on the shore (duration of seawater immersion) and exposure to waves. In the area of Gwaii Haanas National Park Reserve and Haida Heritage Site on Moresby Island, rockdwelling marine lichens are distributed in zones much as they are elsewhere in the world, although some species found abundantly only in Haida Gwaii give the local shores a unique appearance. In common with other areas, there is a conspicuous black band of Verrucaria species (in this case, nine species plus other black lichens) at the upper edge of the intertidal zone. A conspicuous white band of Coccotrema maritimum above the black band is a unique feature of this flora. The unusually large percentage of endemic, near-endemic or disjunct lichen species and their phytogeography suggest that at least the headland rocks along the west coast were refugia during the last glacial maximum. Verrucaria striatula and $\mathrm{V}$. sandstede $i$ are reported for the first time from British Columbia.

Key Words: Maritime lichens, zonation, Haida Gwaii, Pacific Northwest, British Columbia.

Lichens form a dominant, yet often overlooked, component of the maritime vegetation along rocky seashores. They create distinct bands along such shores from polar to tropical seas with maximum abundance, and the most studies, in north-temperate regions (Fletcher 1980; Little and Kitching 1996). The species responsible for these bands in the northeast Pacific (i.e., the Pacific Northwest of North America; see the cover photo, and Plate 64 in Brodo et. al. 2001: 77), however, have rarely been investigated.

The shoreline lichen vegetation of Gwaii Haanas National Park Reserve and Haida Heritage Site can be understood in the context of the total lichen flora of Haida Gwaii, British Columbia. Five field trips by the senior author to Haida Gwaii since 1967 have revealed a diverse lichen flora of about 580 species with more than 25 new to science (Brodo 1995). Many of the species are rare worldwide, and more than a dozen are endemic to Haida Gwaii or are known only from a few nearby localities in southeast Alaska and Vancouver Island. Further, many species are disjuncts, having their nearest additional locality thousands of kilometres distant, often in western Europe, Asia or the southern hemisphere (Brodo 1992).

With the establishment of Gwaii Haanas as a National Park Reserve, there is a need to develop a baseline inventory of lichen species for various uses, for example, to facilitate the conservation of lichen biodiversity (Hunter and Webb 2002), to track human and natural perturbations, to assist in nature interpretation, and to aid studies of shoreline ecology. Lichens are well-known indicators of environmental health in use world-wide (Nimis et al. 2002). Regionally, they have been used for air quality monitoring in the Tongass National Forest in southeast Alaska (Geiser et el. 1994*). In addition, lichen studies have been made to evaluate the effects of oil spills and post-spill cleaning on marine ecosystems (Lallemant and Van Haluwyn 1981; Fletcher and Crump 2002). A knowledge of maritime lichens is clearly relevant to the prospect of oil and gas development in the Hecate Strait separating Haida Gwaii from the British Columbia mainland (Anonymous $2002 *)$.

It is important to know if the shoreline lichens of Haida Gwaii differ from those found elsewhere on the west coast of North America. The only other detailed study of Pacific Northwest marine lichen zonation was done by Ryan (1988a, 1988b) in Washington State, although some observations on shoreline lichens from southern British Columbia were presented by Noble (1982).

We report here on the distribution of lichen species in the upper rocky intertidal zone landward into the salt spray zone in the Gwaii Haanas area. Because splash patterns and exposure affect establishment and growth of shoreline lichens, we examined rocky shores with a range of exposures to wave action from "protected" to "very exposed" to reveal species occurrence patterns. Finally, we compared the rock-dwelling marine lichen flora and zonation of southern Haida Gwaii with the flora and patterns seen in other regions.

\section{Study Area}

Haida Gwaii, known also as the Queen Charlotte Islands, is an archipelago of about 138 islands in the hypermaritime zone of the Pacific Northwest, lying 
about $80 \mathrm{~km}$ off the mainland British Columbia coast between Vancouver Island and southeast Alaska (Figure 1). Its geography, climate and vegetation were described in some detail in Brodo (1995).

The two largest land masses of Haida Gwaii are Graham Island to the north and Moresby Island to the south. The lower elevations of Graham Island (the eastern two-thirds) and Moresby Island (the northern third) have been disturbed by intensive logging activities, but the southern two-thirds of Moresby Island were set aside in 1988 as a National Park Reserve called Gwaii Haanas lying roughly between $52^{\circ}$ and $53^{\circ} \mathrm{N}$ longitude (Figure 2) covering ca. $1470 \mathrm{~km}^{2}$ of land and ca. $1700 \mathrm{~km}$ of shoreline (Sloan and Bartier 2000). The lichen studies described here mainly centre on the extreme southern end of the Park Reserve, at the tip of Moresby Island and on Kunghit Island (Figures 2 and 3 ).

\section{Methods}

To characterize our sample locations, we used Gwaii Haanas' shoreline classification system (Harper et al. 1994*). This is in the park's geographic information system (GIS) and is based largely upon substrate type, texture and exposure to wave action. This system was first developed in Gwaii Haanas and has since become the standard physical shoreline classification system of British Columbia (Howes et al. 1994*) and Washington State [http://www2.wadnr.gov/nearshore/index.asp]. The system has a biological zoning component in which visible lichens are coarsely grouped into a "Verrucaria band" (Searing et al. 1995). The British Columbia scheme has been used in broad-scale regional studies of intertidal species diversity (Zacharias and Roff 2001).

In Harper et al. (1994*), lichens are mentioned as forming conspicuous shoreline bands. There are references to the "Verrucaria zone" and the "white lichen zone," but the diversity of species is overlooked. For example, it is not made clear that the Verrucaria zone consists of nine black Verrucaria species and other dark lichens (Brodo and Santesson 1997), and that the white zone is caused by the dominance of Coccotrema maritimum, a species described from Haida Gwaii, whose closest relatives are in Asia and the southern hemisphere. It is rare in the Pacific Northwest outside Haida Gwaii and adjacent coastal regions (Brodo 1973). Other lichens of intertidal rocks also proved to be new to science and generally restricted to Haida Gwaii and nearby coastal localities. These include Caloplaca litoricola, Fuscidea thomsonii, Verrucaria schofieldii, V. epimaura, and Porina pacifica (Brodo 1984; Brodo and Wirth 1998; Brodo and Santesson 1997; Brodo 2004). Several other novelties remain to be formally described.

Fourteen locations within Gwaii Haanas and one on Limestone Island were sampled (Figures 2, 3). At each location, one to three transects were laid out for a total of 18 transects. A $12 \mathrm{~m}$ tape measure was deployed conforming closely to the rock surface and perpendicular to the high tide line. Transects usually began at the upper limit of the rockweed (Fucus gardneri) and barnacle (Balanus and Semibalanus spp.) zone (the "FB zone," approximating the mean high water level [MHW]) and ran landward to the point at which terrestrial vascular plants or mosses began. This distance was divided into eight or nine equal sections to give approximately nine to ten quadrat points. Because exposed, wave-splashed beaches and shallow slopes produced longer transects than those on protected, relatively steep shores, the increments of height above the FB zone from quadrat to quadrat were not uniform, nor were the distances between quadrats.

At each quadrat point, a $10 \times 10 \mathrm{~cm}$ grid on transparent plastic with a hundred $1-\mathrm{cm}^{2}$ squares, was centered on the transect tape. All lichen species under the grid were recorded together with their coverage in percent (each square representing $1 \%$ coverage). For smooth rocks, the coverage readings were fairly accurate, but with increasing surface roughness, the estimates were correspondingly approximate. After the quadrats were sampled and the lichen data recorded, the vertical height of each quadrat above the starting point in the FB zone was recorded.

\section{Results}

The 18 transects were sorted and analyzed according to degree of shoreline exposure from Protected to Very Exposed, based on Harper et al. (1994*), as listed in Table 1. Two locations had multiple transects, there were no transects for localities 6 or 10, and transect 11 had incomplete data and was excluded. Limestone transects are indicated (L) and all other transects were over mixed volcanic and fine-grained sedimentary rocks characteristic of the region's shoreline (Sutherland Brown and Yorath 1989).

The transects in Gwaii Haanas yielded 43 lichen species. Sixty-seven rock-dwelling species occurring on maritime rocks are currently known from Haida Gwaii as a whole. An annotated list of all shoreline species in Haida Gwaii is presented as an Appendix. This updates the list in Sloan and Bartier (2000; Appendix B, Part 2) compiled by the senior author based on specimens at the National Herbarium of Canada (CANL), Ottawa. The zones indicated in Sloan and Bartier (2000) were assigned tentatively, based on label data, and have been corrected in this study. Two of the lichens from our transects (Verrucaria striatula and V. sandstedei) are new lichens for Haida Gwaii (and British Columbia), and ten others were not included in the Sloan and Bartier (2000) list because they were not regarded to be maritime. These are: Adelolecia kolaensis, Gyalecta jenensis, Opegrapha gyrocarpa, Parmelia saxatilis, Placopsis lambii, Porpidia contraponenda, $P$. speirea and $P$. thomsonii. Many relatively common maritime and marine lichens found elsewhere in Haida Gwaii were not seen in the Gwaii Haanas transects. These include Caloplaca inconspecta, 


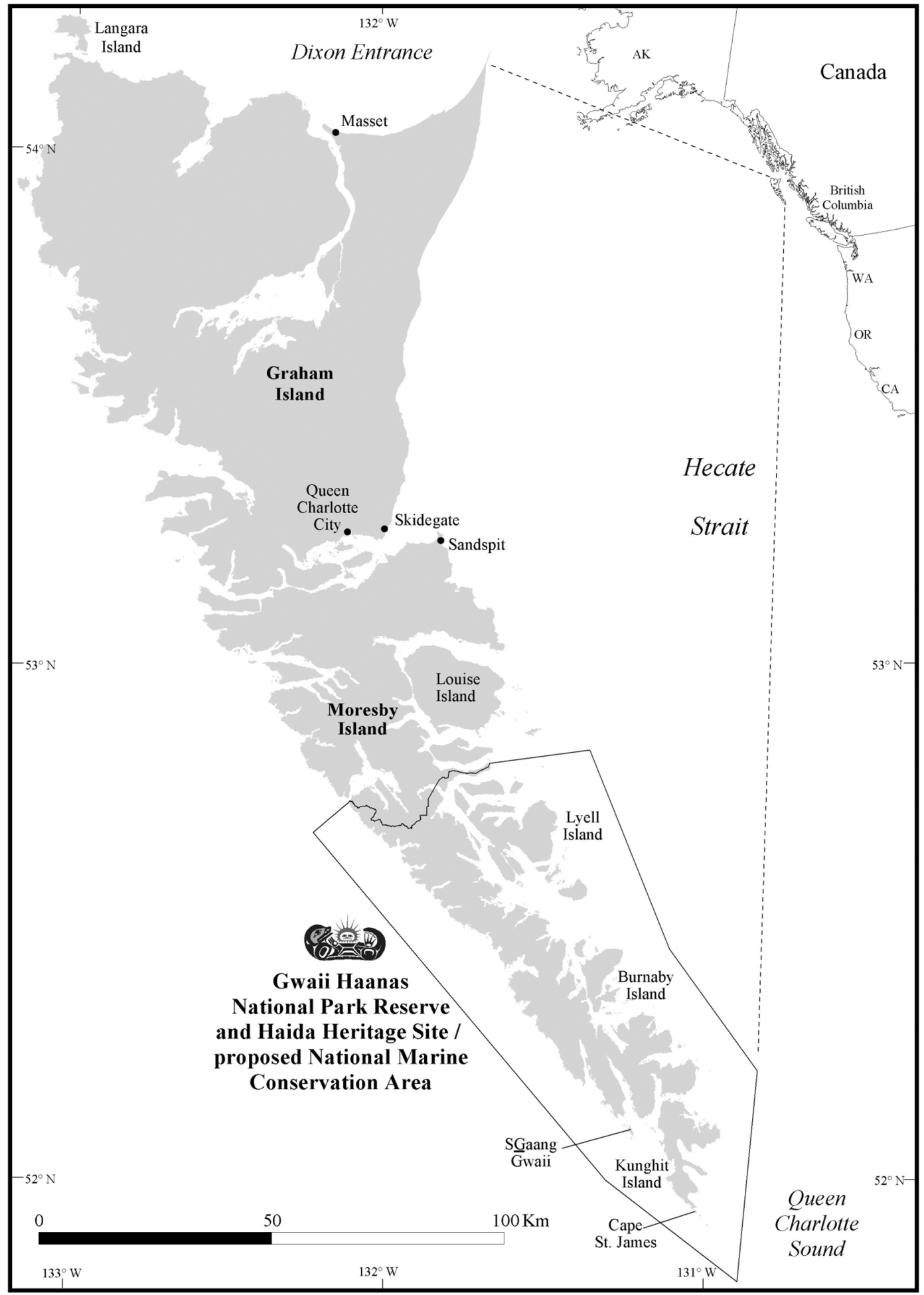

FIgURE 1. Location of Gwaii Haanas within Haida Gwaii (Queen Charlotte Islands) including some of the larger islands. 


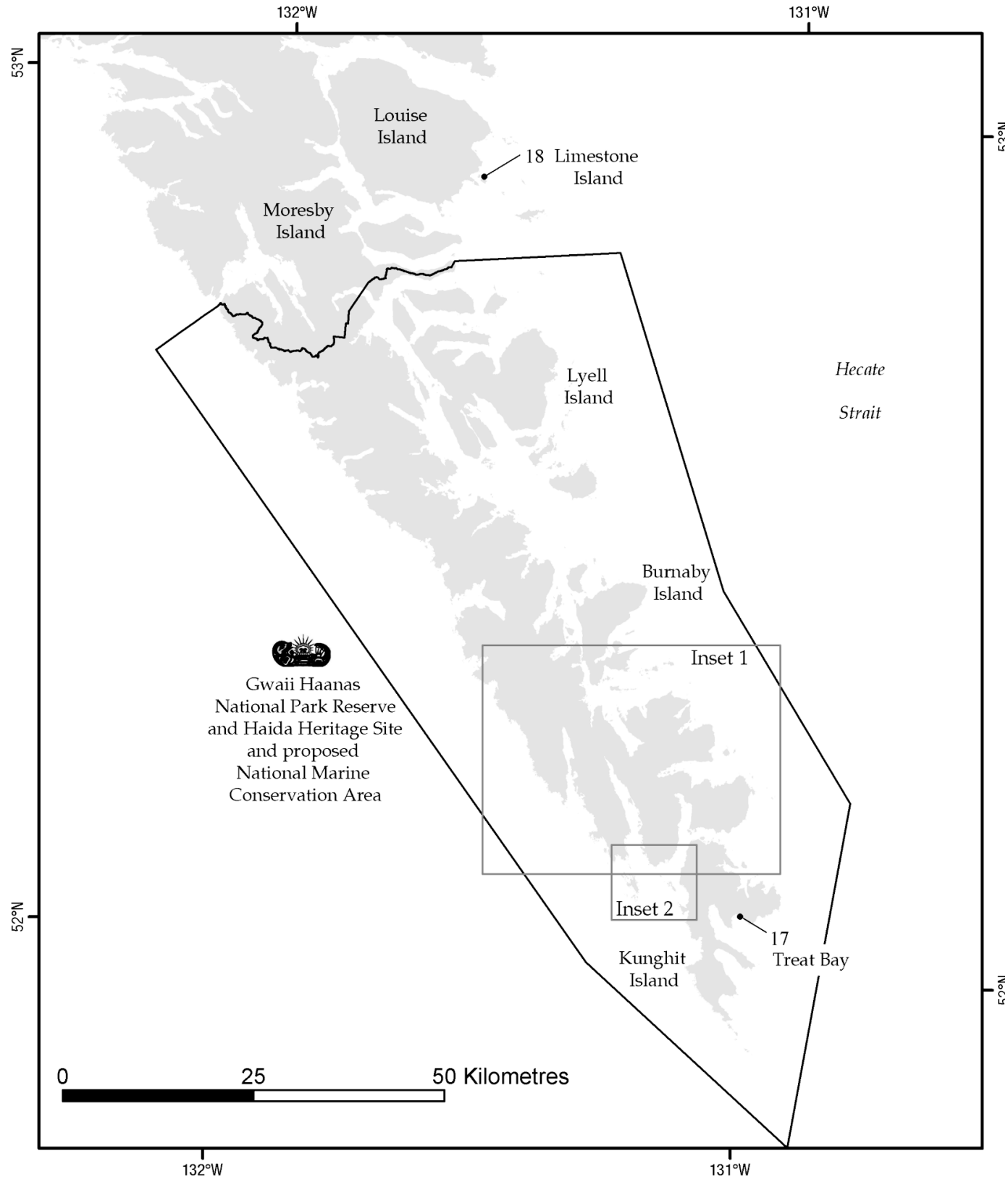

FIGURE 2. Map of the Gwaii Haanas area showing Limestone Island (location 18) to the north and Treat Bay (location 17) to the south of the insets (see Figure 3 for insets).

Catillaria calybeia, Rhizocarpon hensseniae and Rinodina gennari. At least one lichen (Porina pacifica) was found growing abundantly just outside the quadrats on a protected shore.

The frequency of occurrence $(\%)$ of each species in each transect is listed according to shore exposure class in Table 2. Verrucaria maura occurred in all transects on all shores. Among the eight most abundant lichens (frequencies exceeding 50\% in all transects), four are endemic or nearly endemic to Haida Gwaii: Caloplaca litoricola, Coccotrema maritimum, Verrucaria epimaura and V. schofieldii; and one is endemic to the coastal Pacific Northwest (Herteliana alaskensis). The semi-exposed shores had the most species and the most exposed shores yielded the fewest species.

The results of the transect observations, expressed as metres above the FB (Fucus/barnacle) zone, are given in Tables 3 and 4 organized according to the degree of 

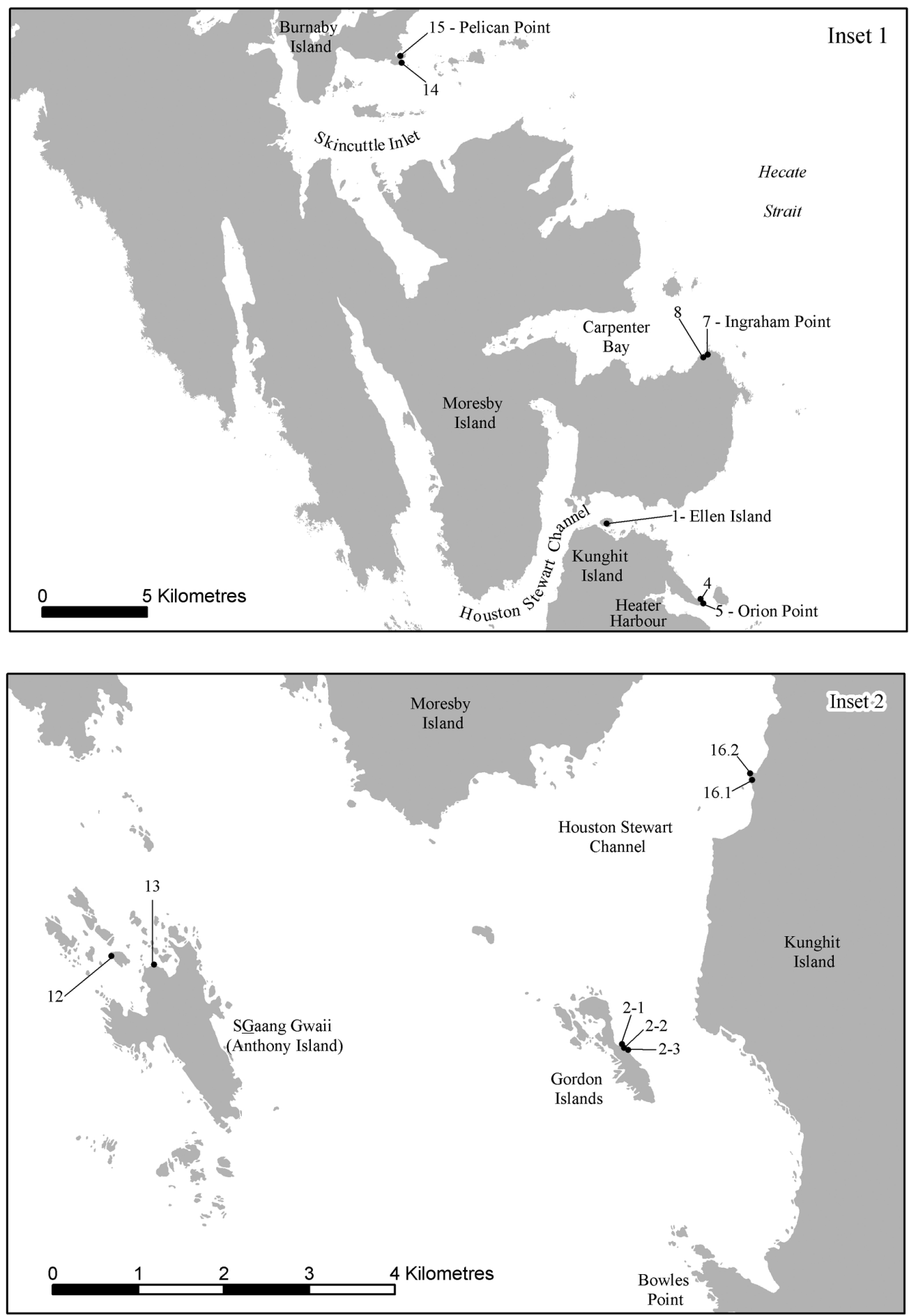

FIGURE 3. Inset maps from Figure 2 showing lichen sampling locations 1-16 within Gwaii Haanas (see Table 1). 
TABLE 1. Locations of shore lichen transects in the Gwaii Haanas area grouped according to the shore exposure classification of Harper et al. (1994).

\begin{tabular}{lllll}
\hline \hline Exposure Class & Location Name & Transect No. ${ }^{\mathrm{a}}$ & Latitude $\left({ }^{\mathrm{o}} \mathrm{N}\right)$ & Longitude $\left({ }^{\circ} \mathrm{W}\right)$ \\
\hline Protected & Carpenter Bay & 9 & 131.1660 & 52.2312 \\
& SGaang Gwaii & 13 & 131.2251 & 52.1015 \\
Semi-protected & Limestone Island & $18\left(\mathrm{~L}^{\mathrm{b}}\right)$ & 131.6170 & 52.9086 \\
& Ellen Island & 1 & 131.0918 & 52.1544 \\
Semi-exposed & Orion Point & 5 & 131.0231 & 52.1229 \\
& Gordon Islands & $2-1,2-2,2-3$ & 131.1443 & 52.0967 \\
& Orion Point & 4 & 131.0217 & 52.1241 \\
& Pelican Point & $14\left(\mathrm{~L}^{\mathrm{b}}\right)$ & 131.2615 & 52.3472 \\
& Pelican Point & 15 & 131.2618 & 52.3458 \\
Exposed & Houston-Stewart Channel & $16-1,16-2$ & 131.1261 & 52.1253 \\
& Treat Bay & 17 & 131.0080 & 52.0659 \\
Very exposed & Ingraham Point & 7 & 131.0325 & 52.2321 \\
& Ingraham Point & 8 & 131.0331 & 52.2319 \\
& Gordon Islands & 3 & 131.1493 & 52.0965 \\
& SGaang Gwaii & 12 & 131.2330 & 52.1021 \\
\hline
\end{tabular}

a Two locations (2 and 16) had multiple transects, locations 6 and 10 had no transects, the transect at location 11 was incomplete and excluded.

${ }^{\mathrm{b}} \mathrm{L}=$ limestone rock

exposure of each shore. These data are graphed Figures in 4 and 5, with the ordination based on average minimum values (the base of the thick black line). Because the values for all shore exposures except "Very Exposed" appear to largely overlap with respect to the height above the FB zone, the data are pooled in Table 3 and Figure 4; Table 4 and Figure 5 shows the data only for Very Exposed shores. The data for Quadrat Position (Table 5), being relative, are not greatly affected by shore exposure, so all shores are considered together. The results of all transects with 8-10 quadrats per transect are shown in Figure 6. (Transects having only 6 or 7 quadrats cannot be compared with those having 8-10 transects.)

Translating the continuum of species position into a zonal scheme with names that correspond with previous North American or European studies proved to be challenging. The graphs presented in Figures 4 and 5 based on metres above the upper limit of the FB zone (Tables 3 and 4) were compared to Figure 6 showing the species according to their quadrat placement along the transects (Table 5) with the aim of finding natural breaks in the continua. This was only partially successful. Thus, in Table 6, which presents a summary of the zones, their position and their dominant lichens, a few species are listed twice, in different zonal categories, according to height above the Fucus-barnacle limit versus their relative quadrat position. Our zonal terminology basically follows the British System, especially Fletcher (1973a, 1973b) who, in agreement with Lewis (1961), argued that the zones are best described and defined on biological criteria, not on physical (i.e., tidal) criteria. Lewis (1961) recommended adopting "Littoral Fringe" in place of "Supralittoral Fringe" used by Stephenson and Stephenson (1949) because it better describes the community that inhabits the upper fringe of the intertidal zone, washed by most tides in relatively protected shorelines. We replace Mesic, Submesic and Xeric subdivisions of the Supralittoral Zone with the more easily understood terms Lower, Middle and Upper, respectively. In addition, we find that the term "xeric," even taken in its relative sense, is not an accurate description of a shoreline habitat. Ryan (1988b) used a numbering system for his zones, but they basically followed the British scheme following the distribution of shoreline organisms. O'Clair et al. (1996) used a simplified system based on wave exposure, and this was adopted by Sloan and Bartier (2000). Some zonal synonymy, discussed in detail by Ryan (1988b), is given in the first column of Table 6.

In the Gwaii Haanas area, Verrucaria mucosa and Pyrenocollema halodytes are the most abundant species at the upper edge of the intertidal zone; i.e., the lowest point on our transects, where rockweed or barnacles occur (Lower Littoral Fringe; quadrat 1). They grow there together with some of the smaller and rarer species of Verrucaria such as V. sandstedei and V. striatula. These are generally too small, thin, and scattered to create a black zone and, therefore, are hard to find. The black zone begins with the appearance of the blacker, thicker species of Verrucaria: V. erichsenii, V. maura, V. epimaura and V. schofieldii, all of which can have broad coverage (Table 7) in the Upper Littoral Fringe (quadrats 2-4). Although V. maura continues to be important well up on the shoreline, the community changes its character and color with the appearance of the gray-brown, gray, and orange species such as Herteliana alaskensis, Arthonia phaeobaea, and the near-endemic but abundant Haida Gwaii lichen, Caloplaca litoricola, in the Lower Supralittoral Zone (quadrats 5-7). Also in this zone is Adelolecia kolaensis and the cyanophilic lichen Spilonema revertens. Above this is a poorly defined orange zone (Middle Supra- 
TABLE 2. Percentage occurrence of shoreline lichen species at locations according to shore exposure classification of Harper et al. (1994) in the Gwaii Haanas area. P = protected; SP = semi-protected; SE = semi-exposed; E = exposed; VE = very exposed.

\begin{tabular}{|c|c|c|c|c|c|c|}
\hline \multirow[b]{2}{*}{ Lichen species } & \multirow[b]{2}{*}{$\mathrm{P}(3)$} & \multicolumn{4}{|c|}{$\begin{array}{l}\% \text { occurrence according to shore exposure class } \\
\text { (number of transects) }\end{array}$} & \multirow{2}{*}{$\begin{array}{c}\% \\
\text { occurrence in } \\
\text { all transects }\end{array}$} \\
\hline & & $\mathrm{SP}(2)$ & SE (9) & $\mathrm{E}(2)$ & VE (2) & \\
\hline Verrucaria maura & 100 & 100 & 100 & 100 & 100 & 100 \\
\hline Spilonema revertens & 67 & 100 & 56 & 100 & 50 & 67 \\
\hline Caloplaca litoricola & 33 & 100 & 56 & 100 & 50 & 61 \\
\hline Coccotrema maritimum & 67 & 50 & 67 & 100 & 0 & 61 \\
\hline Verrucaria epimaura & 0 & 100 & 67 & 50 & 100 & 61 \\
\hline Herteliana alaskensis & 67 & 100 & 33 & 100 & 50 & 56 \\
\hline Pyrenocollema halodytes & 67 & 0 & 56 & 50 & 100 & 56 \\
\hline Verrucaria schofieldii & 67 & 100 & 56 & 0 & 0 & 50 \\
\hline Arthonia phaeobaea & 33 & 50 & 33 & 100 & 50 & 44 \\
\hline Verrucaria amphibia & 100 & 0 & 33 & 50 & 0 & 39 \\
\hline Lecidella stigmatea & 67 & 100 & 0 & 0 & 100 & 33 \\
\hline Rhizocarpon geminatum & 33 & 50 & 22 & 0 & 50 & 28 \\
\hline Xanthoria candelaria & 0 & 50 & 22 & 0 & 100 & 28 \\
\hline Amandinea coniops & 0 & 100 & 22 & 0 & 0 & 22 \\
\hline Physcia caesia & 33 & 50 & 22 & 0 & 0 & 22 \\
\hline Porpidia speirea & 0 & 0 & 44 & 0 & 0 & 22 \\
\hline Verrucaria erichsenii & 0 & 0 & 33 & 0 & 50 & 22 \\
\hline Verrucaria mисоsa & 67 & 0 & 22 & 0 & 0 & 22 \\
\hline Caloplaca flavogranulosa & 33 & 0 & 22 & 0 & 0 & 17 \\
\hline Collema fecundum & 33 & 0 & 11 & 50 & 0 & 17 \\
\hline Fuscidea thomsonii & 0 & 0 & 22 & 50 & 0 & 17 \\
\hline Adelolecia kolaensis & 33 & 50 & 0 & 50 & 0 & 17 \\
\hline Verrucaria degelii & 0 & 0 & 33 & 0 & 0 & 17 \\
\hline Verrucaria sandstedei & 0 & 0 & 33 & 0 & 0 & 17 \\
\hline Lecanora muralis & 0 & 50 & 0 & 0 & 50 & 11 \\
\hline Ochrolechia subplicans & 0 & 0 & 11 & 50 & 0 & 11 \\
\hline Parmelia saxatilis & 0 & 0 & 11 & 50 & 0 & 11 \\
\hline Placopsis lambii & 0 & 0 & 22 & 0 & 0 & 11 \\
\hline Porpidia thomsonii & 0 & 0 & 11 & 50 & 0 & 11 \\
\hline Rhizocarpon haidensis ined. & 0 & 0 & 22 & 0 & 0 & 11 \\
\hline Aspicilia caesiocinerea & 0 & 50 & 0 & 0 & 0 & 6 \\
\hline Caloplaca citrina & 0 & 0 & 11 & 0 & 0 & 6 \\
\hline Caloplaca rosei & 0 & 50 & 0 & 0 & 0 & 6 \\
\hline Caloplaca verruculifera & 0 & 0 & 0 & 0 & 50 & 6 \\
\hline Candelariella sp. & 0 & 50 & 0 & 0 & 0 & 6 \\
\hline Fuscopannaria maritima & 0 & 0 & 11 & 0 & 0 & 6 \\
\hline Gyalecta jenensis & 0 & 0 & 11 & 0 & 0 & 6 \\
\hline Lecanora sp. \#2 & 0 & 50 & 0 & 0 & 0 & 6 \\
\hline Lecanora sp. \#1 & 0 & 50 & 0 & 0 & 0 & 6 \\
\hline Lecanora straminea & 0 & 0 & 0 & 0 & 50 & 6 \\
\hline Opegrapha gyrocarpa & 33 & 0 & 0 & 0 & 0 & 6 \\
\hline Opegrapha sp. & 0 & 0 & 11 & 0 & 0 & 6 \\
\hline Porina pacifica & 33 & 0 & 0 & 0 & 0 & 6 \\
\hline Porpidia carlottiana & 0 & 50 & 0 & 0 & 0 & 6 \\
\hline Porpidia contraponenda & 0 & 0 & 11 & 0 & 0 & 6 \\
\hline Rhizocarpon hochstetteri s. str & 33 & 0 & 0 & 0 & 0 & 6 \\
\hline Verrucaria sp. \#5 & 0 & 0 & 11 & 0 & 0 & 6 \\
\hline Verrucaria striatula & 0 & 0 & 0 & 0 & 50 & 6 \\
\hline Total lichen species & 19 & 21 & 33 & 15 & 15 & \\
\hline
\end{tabular}

littoral Zone; quadrats 7-8) with Caloplaca flavogranulosa, C. rosei (both west coast endemics) and the widespread Xanthoria candelaria, as well as the inconspicuous crust, Rhizocarpon "haidensis." The Upper Supralittoral Zone (quadrats 8-9) almost at the upper edge of the beach is well marked by the dominance of the pinkish white lichen, Coccotrema mari- timum, which forms a conspicuous white band on the coastal rocks of Haida Gwaii, especially on the Pacific side, although it is less common outside of the archipelago. Accompanying the Coccotrema are such widespread lichens as Placopsis lambii, various species of Rhizocarpon, and rarer west coast species such as Ochrolechia subplicans. Higher on the shore and influ- 
TABle 3. Summary data for Protected to Exposed shores, metres above Fucus/barnacle zone (16 quadrats).

\begin{tabular}{|c|c|c|c|c|c|}
\hline Species & $\begin{array}{c}\# \\
\text { quadrants }\end{array}$ & $\begin{array}{c}\text { Extreme } \\
\text { minimum }\end{array}$ & $\begin{array}{c}\text { Average } \\
\text { minimum (m) }\end{array}$ & $\begin{array}{c}\text { Average } \\
\text { maximum (m) }\end{array}$ & $\begin{array}{c}\text { Extreme } \\
\text { maximum }(\mathrm{m})\end{array}$ \\
\hline Adelolecia kolaensis & 3 & 1.35 & 1.43 & 2.03 & 3.15 \\
\hline Arthonia phaeobaea & 7 & 0.55 & 1.04 & 1.34 & 2.40 \\
\hline Aspicilia caesiocinerea & 1 & 2.05 & 2.05 & 3.15 & 3.15 \\
\hline Caloplaca citrina & 1 & 1.05 & 1.05 & 1.05 & 1.05 \\
\hline Caloplaca flavogranulosa & 3 & 1.24 & 1.85 & 1.85 & 2.20 \\
\hline Caloplaca litoricola & 10 & 0.55 & 1.07 & 1.43 & 3.15 \\
\hline Caloplaca rosei & 1 & 2.05 & 2.05 & 2.65 & 2.65 \\
\hline Candelariella sp. & 1 & 2.65 & 2.65 & 2.65 & 2.65 \\
\hline Coccotrema maritimum & 11 & 1.10 & 2.05 & 2.32 & 3.60 \\
\hline Collema fecundum & 3 & 0.80 & 1.40 & 1.50 & 1.90 \\
\hline Fuscidea thomsonii & 3 & 2.20 & 2.73 & 2.73 & 3.60 \\
\hline Fuscopannaria maritima & 1 & 2.40 & 2.40 & 2.40 & 2.40 \\
\hline Gyalecta jenensis & 1 & 0.90 & 0.90 & 0.90 & 0.90 \\
\hline Herteliana (Bacidia) alaskensis & 9 & 0.60 & 1.08 & 1.20 & 2.45 \\
\hline Lecanora muralis & 2 & 2.65 & 2.65 & 2.65 & 2.65 \\
\hline Lecanora sp. no. 1 & 1 & 0.55 & 0.55 & 0.55 & 0.55 \\
\hline Lecanora sp. no. 2 & 1 & 0.90 & 0.90 & 0.90 & 0.90 \\
\hline Lecidella stigmatea & 4 & 0.60 & 1.25 & 1.30 & 2.05 \\
\hline Ochrolechia subplicans & 2 & 1.80 & 2.10 & 2.40 & 2.40 \\
\hline Opegrapha gyrocarpa & 1 & 1.83 & 1.83 & 1.83 & 1.83 \\
\hline Opegrapha sp. & 1 & 1.80 & 1.80 & 2.30 & 2.30 \\
\hline Parmelia saxatilis & 2 & 2.00 & 2.20 & 2.20 & 2.40 \\
\hline Physcia caesia & 4 & 1.00 & 1.11 & 1.99 & 3.15 \\
\hline Placopsis lambii & 2 & 1.85 & 1.93 & 2.13 & 2.40 \\
\hline Porina pacifica & 1 & 2.70 & 2.70 & 3.60 & 3.60 \\
\hline Porpidia carlottiana & 1 & 1.50 & 1.50 & 1.50 & 1.50 \\
\hline Porpidia contraponenda & 1 & 1.60 & 1.60 & 1.60 & 1.60 \\
\hline Porpidia speirea & 4 & 1.10 & 2.28 & 2.44 & 3.60 \\
\hline Porpidia thomsonii & 2 & 2.00 & 2.05 & 2.05 & 2.10 \\
\hline Pyrenocollema halodytes & 8 & -0.20 & 0.00 & 0.00 & 0.35 \\
\hline Rhizocarpon geminatum & 4 & 1.70 & 2.53 & 2.61 & 3.15 \\
\hline Rhizocarpon haidensis & 2 & 1.25 & 2.08 & 2.55 & 2.90 \\
\hline Rhizocarpon hochstetteri s. str & 1 & 1.30 & 1.30 & 1.30 & 1.30 \\
\hline Spilonema revertens & 11 & 0.60 & 1.65 & 2.21 & 3.60 \\
\hline Verrucaria amphibia & 7 & 0.20 & 0.44 & 0.61 & 0.69 \\
\hline Verrucaria degelii & 3 & 0.30 & 0.32 & 0.32 & 0.35 \\
\hline Verrucaria epimaura & 9 & 0.25 & 0.45 & 0.81 & 2.25 \\
\hline Verrucaria erichsenii & 3 & 0.00 & 0.35 & 0.87 & 0.90 \\
\hline Verrucaria maura & 16 & -0.20 & 0.45 & 1.93 & 3.60 \\
\hline Verrucaria mисоsa & 4 & -0.20 & -0.05 & 0.08 & 0.20 \\
\hline Verrucaria sandstedei & 3 & 0.00 & 0.20 & 0.33 & 0.35 \\
\hline Verrucaria schofieldii & 9 & -0.15 & 0.62 & 0.78 & 1.50 \\
\hline Verrucaria sp. \#5 & 1 & 0.90 & 0.90 & 1.05 & 1.05 \\
\hline Xanthoria candelaria & 3 & 1.40 & 1.97 & 2.33 & 3.65 \\
\hline
\end{tabular}

enced only by intermittent salt spray, is the Terrestrial Zone (quadrats 9-10), characterized by widespread nonmaritime but salt-tolerant species such as Parmelia saxatilis as well a Haida Gwaii endemic, Fuscidea thomsonii, and a few lichens restricted to the Pacific Northwest, such as Fuscopannaria maritima and Porpidia carlottiana. The bird rock community (ornithocoprophilous lichens), including Lecanora straminea, L. muralis, and Caloplaca verruculifera, also occurs in this zone.

In comparing the graph showing zonation on Protected to Exposed shores (Figure 4) with the graph dealing with Very Exposed shores (Figure 5), it is immediately apparent that on very exposed shorelines, most of the lichen species are much higher on the shore, the zones themselves are much broader (reflecting the height of wave splash), and not all species are in the same relative quadrat position. For example, the cyanobacterial lichen, Spilonema revertens, which mainly occurs in the central section of the transects (Middle Suppralittoral) on Protected to Exposed shores, is found at the top of the transects (Terrestrial) on Very Exposed shores. Verrucaria maura begins to invade the rock over a metre above the Fucus/barnacle limit, and other shoreline lichens are proportionally higher on the shore. The five species at the top of the transects are terrestrial, but salt-tolerant, lichens, not really maritime. Also unique to the Very Exposed shores are the 
TABLE 4. Summary data for Very Exposed shores, metres above Fucus/barnacle zone (2 transects).

\begin{tabular}{lccccc}
\hline \hline Species & $\begin{array}{c}\# \\
\text { quadrants }\end{array}$ & $\begin{array}{c}\text { Extreme } \\
\text { minimum }\end{array}$ & $\begin{array}{c}\text { Average } \\
\text { minimum (m) }\end{array}$ & $\begin{array}{c}\text { Average } \\
\text { maximum (m) }\end{array}$ & $\begin{array}{c}\text { Extreme } \\
\text { maximum (m) }\end{array}$ \\
\hline Arthonia phaeobaea & 1 & 2.05 & 2.05 & 2.05 & 2.05 \\
Caloplaca litoricola & 1 & 2.05 & 2.05 & 3.65 & 3.65 \\
Caloplaca verruculifera & 1 & 3.65 & 3.65 & 3.65 & 3.65 \\
Herteliana alaskensis & 1 & 3.65 & 3.65 & 3.65 & 3.65 \\
Lecanora muralis & 1 & 6.70 & 6.70 & 6.70 & 6.70 \\
Lecanora straminea & 1 & 3.65 & 3.65 & 3.65 & 3.65 \\
Lecidella stigmatea & 2 & 2.75 & 4.73 & 4.83 & 6.70 \\
Pyrenocollema halodytes & 2 & 0.00 & 0.00 & 0.00 & 0.00 \\
Rhizocarpon geminatum & 1 & 6.70 & 6.70 & 6.70 & 6.70 \\
Spilonema revertens & 1 & 5.70 & 5.70 & 6.70 & 6.70 \\
Verrucaria epimaura & 2 & 1.75 & 2.23 & 1.38 & 2.70 \\
Verrucaria erichsenii & 1 & 0.70 & 0.70 & 4.83 & 1.70 \\
Verrucaria maura & 2 & 1.10 & 1.40 & 1.10 & 6.70 \\
Verrucaria schofieldii & 1 & 1.10 & 1.10 & 0.00 & 1.10 \\
Verrucaria striatula & 1 & 0.00 & 0.00 & 5.18 & 0.00 \\
Xanthoria candelaria & 2 & 3.65 & 5.18 & & 6.70 \\
- & & & & & \\
\hline
\end{tabular}

large areas of uncolonized rock (bare of lichens as well as barnacles or marine algae).

The relative zonal position of some lichen species on protected shores differs when comparing relative quadrat position and actual distance above the FB zone (compare Figures 4 and 6). This may be due to the ability of these species to occupy broader zones than others, coupled with the method of averaging minimum and maximum values to draw the charts. The species included in more than one zonal category are marked with an asterisk (*) or exclamation (!) in Table 6.

Species richness (diversity) appears to be greatest on Semi-exposed shores (33 species) but, since this category of exposure has the largest number of transects (9), the significance of this number is difficult to evaluate. If one combines the lists in Table 2 for Protected and Semi-protected shores (5 transects) and those of Exposed and Very Exposed shores (4 transects), the numbers of species are closer: P+SP: 29 species; SE: 33 species; E+VE: 23 species. Interestingly, the Very Exposed shores, with only 16 species, include 3 species found in no other exposure type, Verrucaria striatula, Caloplaca verruculifera and Lecanora straminea.

One indication of species importance along the rocky shores is the ability of each species to form large patches, i.e., with high coverage values. Table 7 summarizes the coverage classes of all the species that appeared in quadrats in this study. Some species, and even species groups, are clearly able to cover larger areas than others. Almost all the black Verrucaria species, for example, are able to cover over $50 \%$ of the $100 \mathrm{~cm}^{2}$ quadrats, which is why they form a conspicuous black belt on the shore. Similarly, Coccotrema maritimum forms large patches as does Caloplaca litoricola and Ochrolechia subplicans. Some species never dominate their zones, however, always occurring in small patches even if they are frequently en- countered. Examples are Spilonema revertens, Pyrenocollema halodytes, Herteliana alaskensis and Arthonia phaeobaea.

Rock type generally has a major influence on species composition in lichen communities, but some species are more tolerant of varying rock type than others. Verrucaria mucosa was especially abundant on limestone although present on siliceous rock as well. Some lichens found only, or most commonly, on the limestone transects were Verrucaria amphibia, V. species number 5, Caloplaca citrina and Gyalecta jenensis. Pyrenocollema halodytes occurs on limestone rocks as well as on barnacles (both rich in calcium carbonate). On the other hand, many common lichens; e.g., Coccotrema maritimum, Caloplaca litoricola, Verrucaria epimaura, Herteliana alaskensis and Collema fecun$d u m$, were found only on siliceous rock. Species apparently oblivious to rock chemistry include Verrucaria maura and V. schofieldii.

\section{Discussion}

Marine and maritime lichens distribute themselves on rocky shorelines in response to many factors, with the dominant influences being wave exposure and, particularly, immersion duration (Southward 1958; Fletcher 1973a; Taylor 1982). Fletcher (1973a) said that lichens such as Verrucaria mucosa and V. striatula, which grow among the barnacles in the upper intertidal zone, require $52 \%$ submergence per year, the highest amount for any lichen. There is experimental evidence (Ramkaer 1977) that spore germination and hyphal growth at young stages of development are influenced by salt concentrations, and that the ability of different lichens to become established in shoreline habitats is positively correlated with their position on shoreline rocks. Those lowest on the shore (longest immersion duration) are the species that have best germination and hyphal growth under moderate or even high concentrations of seawater. Mature thalli 
Table 5. Summary data for relative quadrat position for all transects with 8-10 quadrats (15 transects).

\begin{tabular}{|c|c|c|c|c|c|}
\hline Species & $\begin{array}{c}\# \\
\text { quadrants } \\
\end{array}$ & $\begin{array}{l}\text { Extreme } \\
\text { minimum }\end{array}$ & $\begin{array}{c}\text { Average } \\
\text { minimum (m) }\end{array}$ & $\begin{array}{c}\text { Average } \\
\text { maximum (m) }\end{array}$ & $\begin{array}{c}\text { Extreme } \\
\text { maximum }(\mathrm{m})\end{array}$ \\
\hline Adelolecia kolaensis & 3 & 4.00 & 5.67 & 7.00 & 8.00 \\
\hline Amandinea coniops & 4 & 6.00 & 6.50 & 6.50 & 7.00 \\
\hline Arthonia phaeobaea & 7 & 4.00 & 6.00 & 6.57 & 9.00 \\
\hline Aspicilia caesiocinerea & 1 & 6.00 & 6.00 & 8.00 & 8.00 \\
\hline Caloplaca flavogranulosa & 3 & 6.00 & 7.33 & 7.33 & 8.00 \\
\hline Caloplaca litoricola & 10 & 4.00 & 4.80 & 6.30 & 9.00 \\
\hline Caloplaca rosei & 1 & 7.00 & 7.00 & 7.00 & 7.00 \\
\hline Caloplaca verruculifera & 1 & 9.00 & 9.00 & 9.00 & 9.00 \\
\hline Candelariella sp. & 1 & 7.00 & 7.00 & 7.00 & 7.00 \\
\hline Coccotrema maritimum & 9 & 6.00 & 8.00 & 9.00 & 10.00 \\
\hline Collema fecundum & 3 & 5.00 & 6.00 & 6.67 & 7.00 \\
\hline Fuscidea thomsonii & 3 & 9.00 & 9.33 & 9.33 & 10.00 \\
\hline Fuscopannaria maritima & 1 & 9.00 & 9.00 & 9.00 & 9.00 \\
\hline Herteliana alaskensis & 10 & 3.00 & 4.80 & 5.30 & 9.00 \\
\hline Lecanora muralis & 2 & 7.00 & 7.50 & 7.50 & 8.00 \\
\hline Lecanora straminea & 1 & 9.00 & 9.00 & 9.00 & 9.00 \\
\hline Lecanora sp. no.1 & 1 & 4.00 & 4.00 & 4.00 & 4.00 \\
\hline Lecanora sp. no.2 & 1 & 3.00 & 3.00 & 3.00 & 3.00 \\
\hline Lecidella stigmatea & 6 & 4.00 & 6.17 & 6.67 & 8.00 \\
\hline Ochrolechia subplicans & 2 & 7.00 & 8.00 & 9.00 & 9.00 \\
\hline Opegrapha gyrocarpa & 1 & 8.00 & 8.00 & 8.00 & 8.00 \\
\hline Parmelia saxatilis & 2 & 6.00 & 8.50 & 9.00 & 9.00 \\
\hline Physcia caesia & 3 & 6.00 & 6.00 & 7.00 & 8.00 \\
\hline Placopsis lambii & 2 & 8.00 & 8.00 & 8.50 & 9.00 \\
\hline Porina pacifica & 1 & 7.00 & 7.00 & 8.00 & 8.00 \\
\hline Porpidia carlottiana & 1 & 9.00 & 9.00 & 9.00 & 9.00 \\
\hline Porpidia speirea & 3 & 6.00 & 8.00 & 8.67 & 10.00 \\
\hline Porpidia thomsonii & 2 & 8.00 & 8.00 & 8.00 & 8.00 \\
\hline Pyrenocollema halodytes & 9 & 1.00 & 1.00 & 1.00 & 1.00 \\
\hline Rhizocarpon geminatum & 5 & 5.00 & 7.80 & 8.00 & 9.00 \\
\hline Rhizocarpon haidensis & 2 & 7.00 & 7.00 & 9.50 & 10.00 \\
\hline Rhizocarpon hochstetteri s. str & 1 & 8.00 & 8.00 & 8.00 & 8.00 \\
\hline Spilonema revertens & 11 & 5.00 & 6.27 & 7.73 & 10.00 \\
\hline Verrucaria amphibia & 5 & 1.00 & 2.40 & 2.60 & 4.00 \\
\hline Verrucaria degelii & 2 & 1.00 & 1.00 & 1.00 & 1.00 \\
\hline Verrucaria epimaura & 10 & 2.00 & 2.90 & 3.90 & 5.00 \\
\hline Verrucaria erichsenii & 4 & 1.00 & 2.25 & 4.50 & 7.00 \\
\hline Verrucaria maura & 15 & 1.00 & 2.47 & 7.27 & 10.00 \\
\hline Verrucaria тисоsa & 2 & 1.00 & 1.00 & 1.50 & 2.00 \\
\hline Verrucaria sandstedei & 3 & 1.00 & 1.00 & 1.67 & 3.00 \\
\hline Verrucaria schofieldii & 8 & 1.00 & 3.25 & 4.00 & 7.00 \\
\hline Verrucaria striatula & 1 & 1.00 & 1.00 & 1.00 & 1.00 \\
\hline Xanthoria candelaria & 5 & 6.00 & 7.20 & 7.60 & 8.00 \\
\hline
\end{tabular}

might be affected by osmotic problems, acidity (sea water has a relatively high $\mathrm{pH}$ ), and other seawater minerals. Other factors that influence zonation include degree of wetness and seepage of acidic fresh water from the land above the shore (Fletcher 1973b; Ryan 1988b) and excess heating or freezing (Southward 1958). Verrucaria maura occurs far up on exposed shores in depressions or shaded nooks indicating a requirement for moisture. This was noted by European workers, including Fletcher (1973b), who nevertheless regards $V$. maura as one of the more drought-tolerant of the marine Verrucaria species. Fletcher (1973a) found that $V$. maura actually has no requirement for submergence in sea water at all. It can survive with only sea spray. Competition with algae and grazing animals (such as limpets and snails) is regarded to be a significant factor by some observers (Southward 1958; Ryan 1988b) and minimal by others (Fletcher 1973a). We did not see much evidence of grazing on the lichens of Gwaii Haanas.

As noted by Fletcher (1980), the lichen bands can be characterized by life form as well as species. In the Littoral Fringe, all lichens are anatomically unstratified (i.e., without a differentiated cortex, algal layer and medulla) and almost all open by an ostiole rather than having a discoid apothecium. An exception in Gwaii Haanas is Herteliana alaskensis, a lichen with biatorine apothecia found in the Lower Supralittoral Zone 
TABLE 6. Zones formed by lichens on maritime rocks in Gwaii Hanaas. The names of equivalent zones in O'Clair et al. (1996) and Ryan (1988b) are also given. For species listed twice under "Characteristic lichens," an asterisk (*) indicates the lichen's zonal position according to its occurrence in the quadrat series (see Figure 6); an exclamation (!) indicates its zonal position according to its height above the Fucus-barnacle (FB) zone (see Figure 4). P to E = protected to exposed shores; VE = very exposed shores.

\begin{tabular}{lcccc}
\hline \hline & Quad series & m above & & \multicolumn{2}{c}{ Characteristic lichens } \\
\cline { 3 - 4 } Zone Type & Quadrat & FB zone & & P to E \\
\hline
\end{tabular}

Terrestrial (Halophilic)

O'Clair: upper salt spray

Ryan: Zones 2A- 2B
9-10

2.3-3.6

Parmelia saxatilis

Fuscidea thomsonii

Fuscopannaria maritima

Rhizocarpon geminatum!

Lecanora muralis!

Porina pacifica

Caloplaca verruculifera*

Lecanora straminea*

Porpidea speirea!

\begin{abstract}
Upper Supralittoral Zone
O’Clair: mid salt spray

Ryan: Zone 2C-2D
\end{abstract}

\author{
Middle Supralittoral Zone \\ O'Clair: low salt spray \\ Ryan: Zone 2D
}

8-9

2.1-2.6

Coccotrema maratimum

Placopsis lambii

Ochrolechia subplicans

Xanthoria candelaria!

Porpidia thomsonii

Aspicilia caesiocinerea

Rhizocarpon "haidensis"!

Caloplaca rosei!

Porpidea speirea*

Rhizocarpon geminatum*

\section{7-8}

1.4-2.3

Caloplaca flavogranulosa

Caloplaca rosei*

Rhizocarpon "haidensis"*

Lecanora muralis*

Xanthoria candelaria*

Adelolecia kolaensis!

Spilonema revertens!

\author{
Lower Supralittoral Zone \\ O'Clair: splash zone \\ Ryan: Zone 2E
}

\section{$5-7$}

$0.8-1.5$

Herteliana alaskensis

Caloplaca litoricola

Arthonia phaeobaea

Physcia caesia

Collema fecundum

Adelolecia kolaensis*

Spilonema revertens $*$

2-4

O'Clair : high intertidal (p.p.)

Ryan: Zone 3-2E

Littoral Fringe, Lower

O'Clair: high intertidal (p.p.)

Ryan: Zone 4A-3
0.3-0.8

Verrucaria maura

Verrucaria epimaura

Verrucaria erichsenii

Verrucaria schofieldii

Verrucaria amphibia

$1-2 \quad-0.3-0.3$

Pyrenocollema halodytes

Verrucaria striatula

Verrucaria mucosa

Verrucaria sandstedei
Rhizocarpon geminatum

Lecanora muralis

Spilonema revertens

Lecidella stigmatea

Xanthoria candelaria

Caloplaca verruculifera

Herteliana alaskensis

Lecanora straminea

Caloplaca litoricola Arthonia phaeobaea Verrucaria maura

V.epimaura

Verrucaria erichsenii

V. schofieldii

Pyrenocollema halodytes Verrucaria striatula occasionally in the company of black species of Verrucaria. Lichens with apothecia, also having somewhat stratified crustose thalli, first appear in the Lower Supralittoral Zone. Higher still, in the Middle and Upper Supralittoral Zones, the stratified foliose lichens appear. The biological reasons for this phenomenon are fairly easy to surmise. Lichens that are submerged frequently have no need for a loosely organized medulla with air spaces for gas exchange, and their spores are better distributed by oozing out of an ostiole than being shot into the air as would occur from an apothecial disk. Stratified apothecial lichens are adapted for a basically terrestrial life style.

The shift in relative position in the zonation by Spilonema revertens on Very Exposed (where it is Terrestrial) as compared to less exposed shorelines 


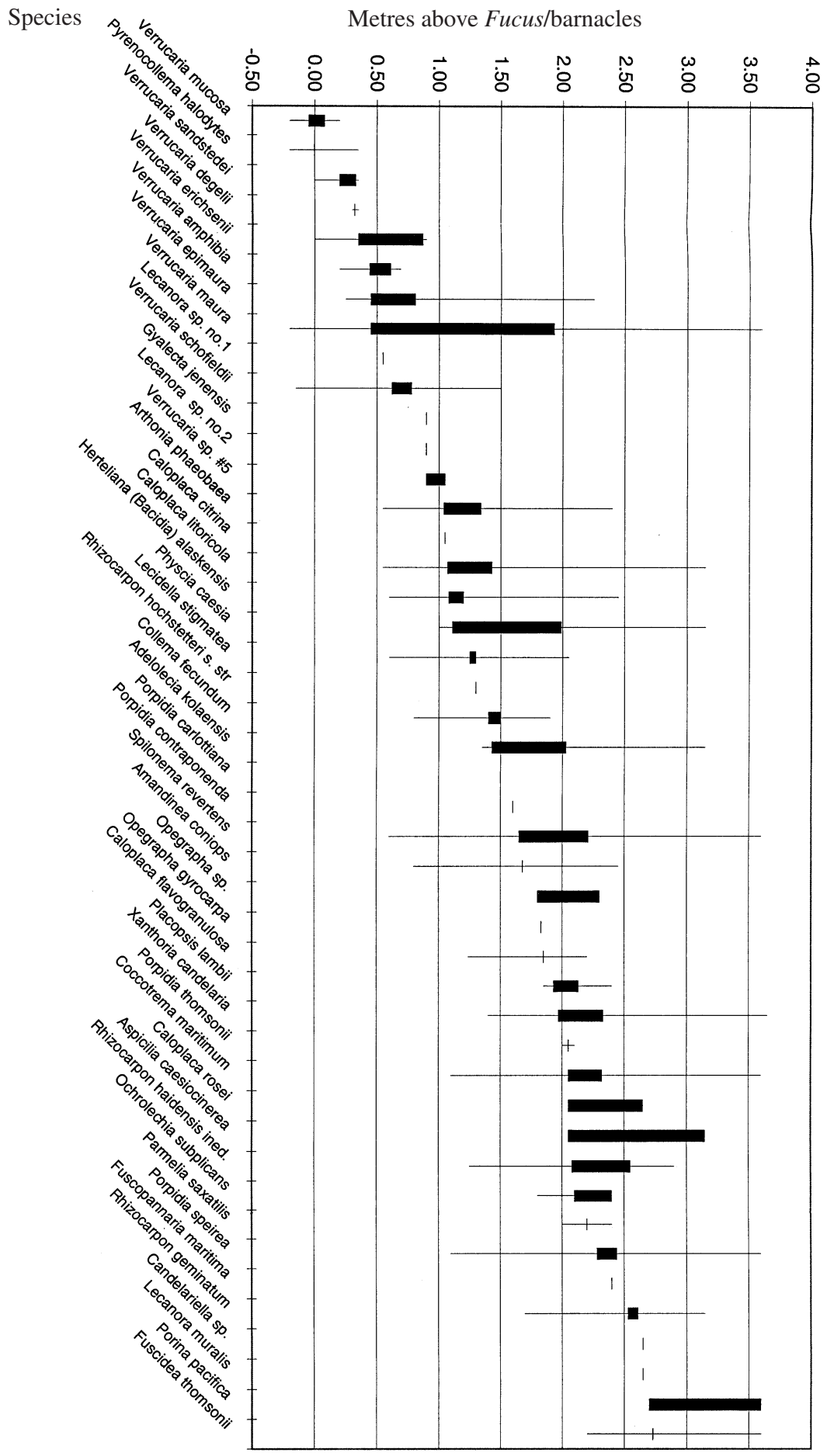

FIGURE 4. Zonation of maritime lichens on Protected to Exposed shores, ordered by metres above the Fucus-barnacle zone. The thick line is the range of average values. The thin lines represent the total range (extreme maximum and minimum) values. 


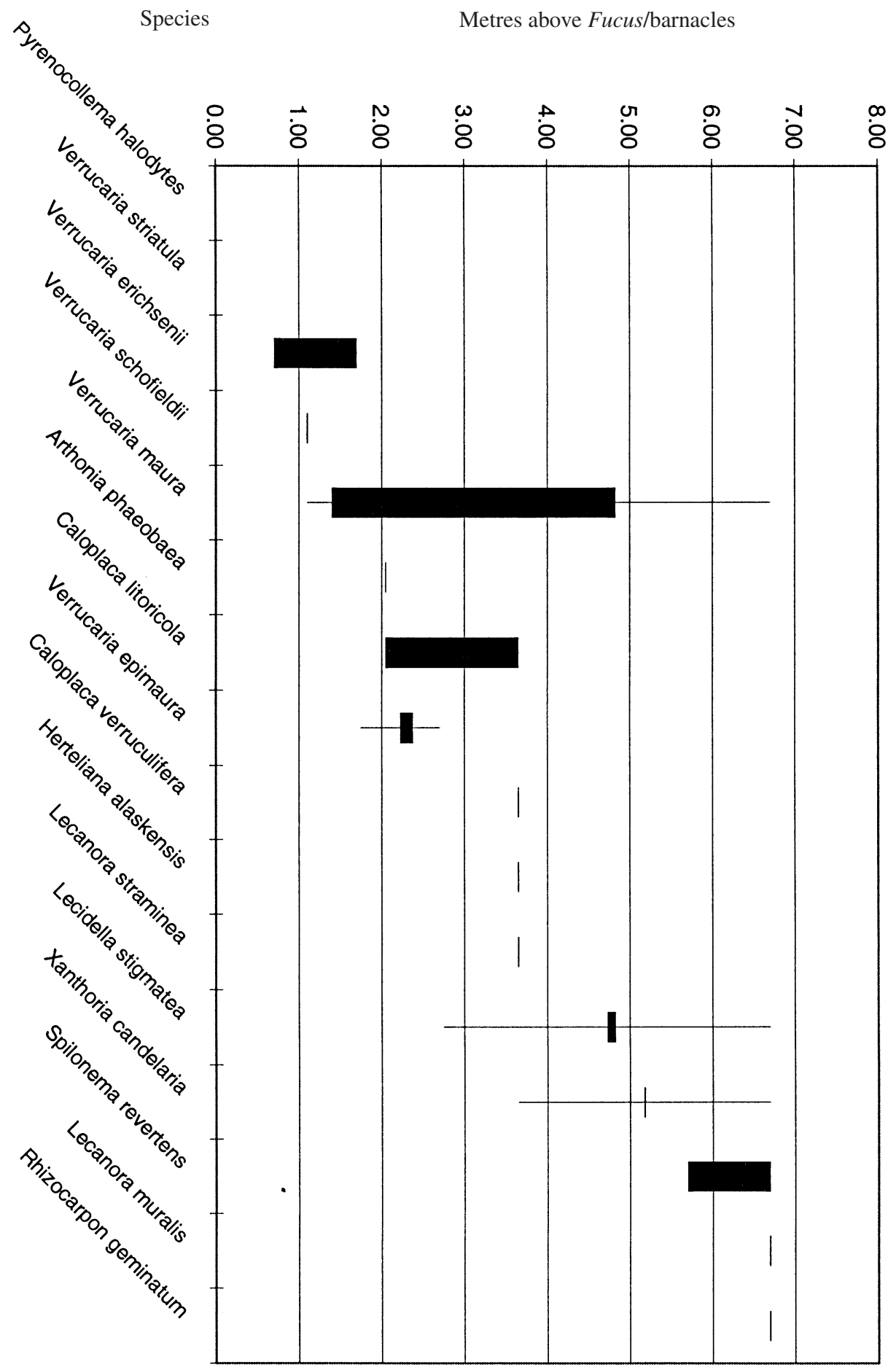

FIGURE 5. Zonation of maritime lichens on Very Exposed shores, ordered by metres above the Fucus-barnacle zone. The thick line is the range of average values. The thin lines represent the total range (extreme maximum and minimum) values. 


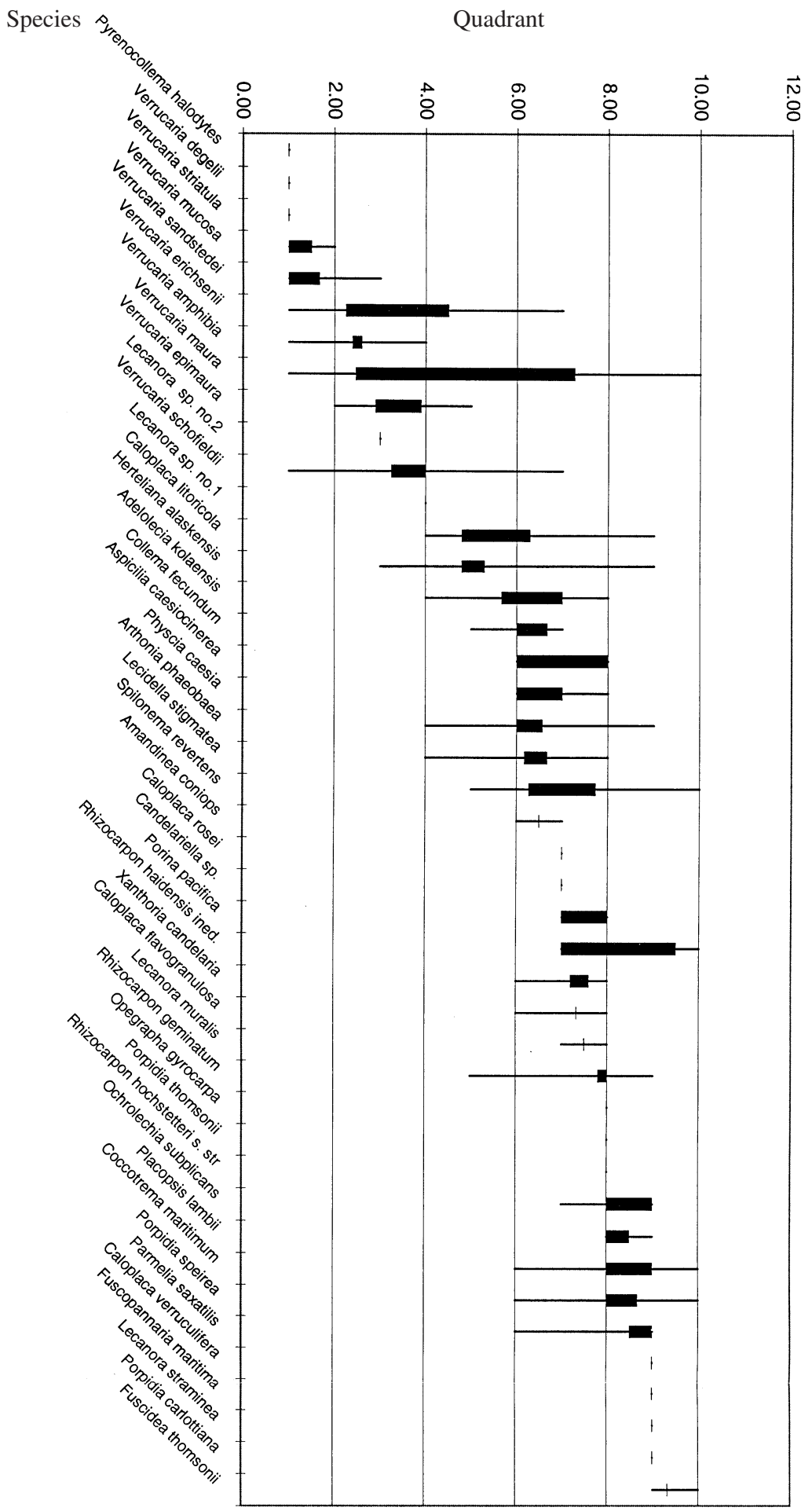

FIgURE 6. Zonation of maritime lichens on Protected to Very Exposed shores, ordered by relative quadrat position. The thick line is the range of average values. The thin lines represent the total range (extreme maximum and minimum) values. 
TABLE 7. The number of quadrats sampled in which lichen species are represented, according to percentage coverage category.

\begin{tabular}{|c|c|c|c|c|c|c|c|c|c|c|c|}
\hline \multirow[b]{2}{*}{ Lichen species } & \multicolumn{6}{|c|}{ Coverage category $(\%)$} & \multirow[b]{2}{*}{$51-60$} & \multirow[b]{2}{*}{$61-70$} & \multirow[b]{2}{*}{$71-80$} & \multirow[b]{2}{*}{$81-90$} & \multirow[b]{2}{*}{$91-100$} \\
\hline & $1-5$ & $6-10$ & $11-20$ & $21-30$ & $31-40$ & $41-50$ & & & & & \\
\hline Adelolecia kolaensis & 4 & 1 & 2 & & & & & & & & \\
\hline Amandinea coniops & 3 & & & & & & & & & & \\
\hline Arthonia phaeobaea & 5 & 1 & 1 & & & & & & & & \\
\hline Aspicilia caesiocinerea & & 1 & 1 & 1 & & & & & & & \\
\hline Caloplaca citrina & & & & 1 & & & & & & & \\
\hline Caloplaca flavogranulosa & 1 & 1 & & 1 & & & & & & & \\
\hline Caloplaca litoricola & 6 & 4 & 3 & 2 & 1 & & & & 1 & & \\
\hline Caloplaca rosei & 2 & & & & & & & & & & \\
\hline Caloplaca verruculifera & & & 1 & & & & & & & & \\
\hline Candelariella $\mathrm{sp.}$ & 1 & & & & & & & & & & \\
\hline Coccotrema maritimum & 1 & & 4 & 2 & 6 & & 2 & 2 & 1 & & \\
\hline Collema fecundum & 3 & 2 & & & & & & & & & \\
\hline Fuscidea thomsonii & & & 3 & & & & & & & & \\
\hline Fuscopannaria maritima & 1 & & & & & & & & & & \\
\hline Gyalecta jenensis & & & 1 & & & & & & & & \\
\hline Herteliana alaskensis & 7 & 4 & & 3 & & & & & & & \\
\hline Lecanora muralis & 2 & & & & & & & & & & \\
\hline Lecanora straminea & & & & 1 & & & & & & & \\
\hline Lecanora sp. \#1 & & & & & & & & 1 & & & \\
\hline Lecanora sp. \#2 & 1 & & & & & & & & & & \\
\hline Lecidella stigmatea & 4 & 2 & & & & & & & & & \\
\hline Ochrolechia subplicans & 1 & & 1 & & & 1 & 1 & & & & \\
\hline Opegrapha gyrocarpa & & & 1 & & & & & & & & \\
\hline Opegrapha sp. & & & 2 & & & & & & & & \\
\hline Parmelia saxatilis & & & 2 & & & & & & & & \\
\hline Physcia caesia & 1 & & 4 & & & & & & & & \\
\hline Placopsis lambii & 2 & 1 & & & & & & & & & \\
\hline Porina pacifica & & & & & & & & & & & \\
\hline Porpidia carlottiana & & & & & & & & & 1 & & \\
\hline Porpidia contraponenda & 1 & & & & & & & & & & \\
\hline Porpidia speirea & 4 & 1 & & & & & & & & & \\
\hline Porpidia thomsonii & 1 & & 1 & & & & & & & & \\
\hline Pyrenocollema halodytes & 10 & & & & & & & & & & \\
\hline Rhizocarpon geminatum & 3 & 1 & 2 & & & & & & & & \\
\hline Rhizocarpon haidensis ined. & 2 & 1 & 1 & & & & & & & & \\
\hline Rhizocarpon hochstetteri s. str & & & & 1 & & & & & & & \\
\hline Spilonema revertens & 17 & 2 & 1 & & & & & & & & \\
\hline Verrucaria amphibia & 2 & 1 & & & & 2 & & & 1 & & 3 \\
\hline Verrucaria degelii & & 1 & & & & & & & & 1 & \\
\hline Verrucaria epimaura & 2 & 3 & 4 & 2 & 3 & 1 & & & & & \\
\hline Verrucaria erichsenii & 1 & 1 & 3 & 1 & & 3 & & & & 1 & 1 \\
\hline Verrucaria maura & 11 & 12 & 8 & 13 & 3 & 5 & 8 & 4 & 12 & 8 & 4 \\
\hline Verrucaria mисоsa & & 1 & & & 2 & 1 & & & & 2 & \\
\hline Verrucaria sandstede $i$ & & 1 & & & & 1 & & & & 1 & \\
\hline Verrucaria schofieldii & 2 & & 2 & 2 & 3 & 1 & & & 1 & 1 & \\
\hline Verrucaria striatula & & 1 & 1 & & & & & & & & \\
\hline Verrucaria sp. \#5 & & & & & & & & & 1 & 1 & \\
\hline Xanthoria candelaria & 4 & & & & 1 & & & & & & \\
\hline
\end{tabular}

(where it is Middle Supralittoral) may be due, in part, to the species' sensitivity to excessive inundation by tidal splash. More likely, it is due to its inability to physically withstand the pounding of waves on highly exposed headland rocks. Spilonema is a microfruticose lichen and is attached to the rock relatively loosely compared to its crustose neighbours. A similar shift in the distribution of the fruticose Lichina pygmaea occurs on European shores (Fletcher 1973a). Spilo- nema revertens is not a particularly maritime lichen, however, being frequently found in inland areas (Brodo et al. 2001).

The species diversity on protected and semiprotected Gwaii Haanas shores is not significantly lower than that of more exposed shores. Chu et al. (2000) found the opposite on Hong Kong shores. They hypothesized that wave-exposed shores have more microhabitats to be exploited than do quiet bays. Our data do not sup- 
port Chu's observations, but our data suffer from uneven sampling in the various exposure categories and may not be as reliable.

Light influences species composition especially on the more terrestrial shoreline habitats (Fletcher 1973a). For example, Caloplaca and Xanthoria species are almost entirely restricted to sunny rocks in Gwaii Haanas. Fletcher (1973a) found that most lichens in the Littoral Fringe and even the Lower Supralittoral Zone are largely indifferent to light conditions, but Ryan (1988b) reported that Verrucaria mucosa only occurs in shaded habitats. This species was found in both unshaded and shaded sites in Gwaii Haanas, although it was more abundant on shaded limestone. Since exposure to sun affects moisture availability and retention, some correlation of species distribution according to shade conditions is to be expected. Shaded shores are almost always also protected shores, so it is difficult to separate the two factors in explaining differences in lichen vegetation.

Shoreline rocks are frequently subject to manuring by sea birds, increasing the nitrogen load (urea and ammonia) and raising the $\mathrm{pH}$ of the rock surface, and this affects the composition of the saxicolous lichen communities, especially in the salt spray zone. Ornithocoprophilous lichens that prefer such habitats include Lecanora straminea, Caloplaca verruculifera, Physcia caesia and Xanthoria candelaria, all present on the shores of Gwaii Haanas wherever the conditions are suitable.

The relative position of the marine and maritime species in Gwaii Haanas agree closely with observations made by others, in so far as there are species in common, e.g., Verrucaria mucosa, V. striatula, Pyrenocollema halodytes occur in the upper edges of the intertidal zone; V. maura appears higher and has a broad distribution; Xanthoria candelaria, Physcia caesia and Caloplaca verruculifera are associated with bird rocks; etc. (Eliasson 1965; Ryan 1988b; Sheard and Ferry 1967; Sheard 1968; Fletcher 1973a; Fletcher 1973b).

The west coast endemics, and especially the maritime lichens closely restricted to Haida Gwaii, comprise 17 of the 67 species listed in the Appendix. It is useful to examine these species to see what their ecological and taxonomic equivalents would be elsewhere in the world. We will begin with ecological relationships.

Caloplaca litoricola, a Haida Gwaii specialty, is in the Supralittoral Caloplaca zone as one would expect, but, since it is grey rather than yellow, it does not help to create an orange zone as other species of Caloplaca do in Europe or even eastern North America. On the other hand, the Pacific Northwest endemics $C$. rosei and $C$. inconspecta, and especially Caloplaca flavogranulosa, are the ecological equivalents of the similar European C. marina (also in western North America from California to Vancouver Island, but not reaching Haida Gwaii; Arup 1992), which is part of the "orange zone" of European shores. Instead of the fruticose cyanophilic lichen, Lichina pygmaea, common in the British Isles (and rare on the American east coast), we have Spilonema revertens, a microfruticose cyanophilic lichen in Gwaii Haanas, although it tends to be higher in the transects than Lichina would appear. Instead of species like the orange foliose lichen, Xanthoria parietina (common in both Europe and along the east coast of North America) in the Middle to Upper Supralittoral Zone, Haida Gwaii has the white crustose lichen Coccotrema maritimum, resulting in a conspicuous white zone replacing the orange zone seen in Europe. We have no ecological equivalent for their maritime saxicolous fruticose lichen, Ramalina siliquosa, but instead of Fuscidea cyathoides, Haida Gwaii has the narrowly endemic F. thomsonii in the Terrestrial zone (Brodo and Wirth 1998).

The distribution of geographically or ecologically separated, closely related taxa (vicariants) with respect to these endemics or near-endemics is especially interesting. The categories of relationships and the taxa involved are summarized below, in most cases, with references to discussions already published.

\section{High Mountain connections}

The following species either have close relatives in the arctic-alpine flora, or have populations/subspecies that are found only on maritime and alpine rocks, not in between.

Caloplaca litoricola: C. exsecuta (Nyl.) Dalla Torre \& Sarnth. (Brodo 1984)

Ochrolechia subplicans: subsp. hultenii is on shoreline rocks; subsp. subplicans grows in the alpine zone from Haida Gwaii to Alaska (Brodo 1988).

Porpidia carlottiana: populations on Haida Gwaii either on shore or in mountains; close to P. glaucophaea (Körber) Hertel \& Knoph in Hertel, an oceanic species (Gowan 1989).

\section{Southern Hemisphere connections}

These species are closely related to species common in the southern hemisphere, either in South America or Australasia.

Coccotrema maritimum: C. cucurbitula common on trees in Chile, etc. as well as in other parts of the Pacific Basin, e.g., Japan (Brodo 1973)

Collema fecundum: C. novozelandicum Degel., on calcareous non-maritime and maritime rocks and soil, South Island, New Zealand (Degelius 1974, 1979)

Verrucaria epimaura: V. durietzii I. M. Lamb, maritime lichen from the Aukland Islands (Brodo and Santesson 1997)

Kohlmeyera complicatula: the same or related species are on maritime rocks in western South America. (Brodo 1976)

\section{Related to widespread maritime species}

These species are most closely related to other maritime lichens.

Lecanora species number 1: L. actophila, L. helicopsis This undescribed Lecanora with a thick, white, xanthone-containing thallus will be discussed in a pub- 
lication in preparation. It is clearly related to other species in the $L$. dispersa aggregate such as those listed above.

L. poliophaea (undescribed subspecies): subsp. poliophaea. The Haida Gwaii populations of $L$. poliophaea differ in some respects from European populations and are probably deserve taxonomic recognition. This will be discussed in the publication in preparation mentioned above.

Verrucaria. schofieldii: V. erichsenii, a widespread supralittoral species (Brodo and Santesson 1997).

\section{Related to widespread non-maritime species}

The following species have their closest relatives as Temperate or Boreal, non-maritime lichens.

Fuscidea thomsonii: F. intercincta (Nyl.) Poelt, $F$. atlantica (H. Magn) P. James \& Poelt, both are European species found in regions with an oceanic climate (Brodo and Wirth 1998; Oberhollenzer and Wirth 1984).

Fuscopannaria maritima: F. thiersii P. M. Jørg., a Pacific Northwest species on iron-rich moist rocks (Jørgensen 2000); and F. leucostictoides Ohlsson, a western American corticolous species (Jørgensen 1978).

Porina pacifica: Porina chlorotica (Ach.) Müll. Arg., widespread northern species on shaded rock faces (Brodo 2004).

Rhizocarpon maritimum ined: $R$. cinereovirens is a Temperate species on shaded and exposed rocks, B. C., Black Hills, Long Island, N.Y. (The species, which will be described in a forthcoming paper, is closely related to $R$. cinereovirens (Fryday 2002: 463).

These phytogeographic relationships of the endemic or near-endemic maritime lichens of Haida Gwaii and their vicariant taxa suggest survival in the area during the Pleistocene glaciations. Relationships with montane species may indicate, as has been suggested (Clague 1989; Heusser 1989), that during the several glacial advances of the Pleistocene, some coastal areas and the highest mountain peaks of Haida Gwaii remained exposed. They would, therefore, have been available for colonization by lichens. It is possible that species that evolved at sea level from montane ancestors were highly restricted to coastal rocks and never were able to reinvade the intervening elevations although the highly exposed and harsh seacoast environment has much in common with alpine habitats and often shares the same or related species. It is probably significant that the closest relative of Coccotrema maritimum, a rockdwelling species, is C. cucubitula, primarily a corticolous species throughout its range. A glacial relic would, of course, have to survive on non-arboreal substrates. Schofield (1989) notes that all the Haida Gwaii endemics among the bryoflora occur on rock or soil.

Many organisms are distributed around the Pacific Rim, or are disjunct from regions thousands of kilometres away. Plants and animals showing these patterns usually are related at the genus level or above, but these relationships show up at the species level in lichens and sometimes bryophytes (Schofield 1989).
The fact that the land mass of Haida Gwaii represents a crustal plate fragment (terrane) that originated off the coast of Peru and and started its northward migration approximately 230 million years ago (SutherlandBrown and Yorath 1989) provides a possible way for the species to have been transported (assuming the species had evolved by that time), although long distance dispersal is another means. Similar patterns are known from bryophytes; e.g., the moss Polytrichadelphus lyellii Mitt, which is known from British Columbia to California. The other 20 species of the genus are from South America, New Zealand and Australia (Persson, H. 1968. The possible migration routes of the species with southern hemisphere affinities are discussed by Brodo (1973).

Maritime lichens on Haida Gwaii that are disjunct with western Europe or even eastern North America probably reveal ancient, probably Tertiary, distribution patterns that were at first continuous but became dissected by climatic and geological events over the past 10-20 million years leaving the Haida Gwaii populations clinging to their outposts in microclimatically suitable habitats. Equivalent patterns among the mosses are common (Schofield 1984).

\section{Conclusions}

Rock-dwelling marine lichens of Gwaii Haanas are distributed in zones much as they are elsewhere in the world, although some species found abundantly only in Haida Gwaii create a unique appearance of these zones, such as the white Coccotrema zone, as compared with other regions. The unusually large percentage of endemic, near-endemic or disjunct species suggests that at least the headland rocks along the west coast were refugia during the last glacial maximum.

\section{Acknowledgments}

We thank Gwaii Haanas (Parks Canada) for funding the summer 2000 fieldwork and Doug Burles and Lee Edenshaw for field assistance. Dr. Fenja Brodo made numerous helpful suggestions on early drafts and assisted with some quadrat studies when not executing her own Gwaii Haanas inventory project. IMB, now retired from the Canadian Museum of Nature, thanks the Museum for appointing him as a Research Associate and providing him with space and facilities for his lichen research. We dedicate this paper to the memory of Bruce Ryan, who first studied the maritime zonation of lichens in the Pacific Northwest and did it so well.

\section{Documents Cited (marked $*$ in text)}

Anonymous. 2002. Final Report-Offshore Oil and Gas Task Force. (http://www.em.gov.bc.ca/Oil\& Gas/offshore/Off shoreOilGasReport/)

Geiser, L. H., C. C. Derr, and K. L. Dillman. 1994. Air quality monitoring on the Tongass National Forest. Methods and baselines using lichens. USDA-Forest Service, Alaska Region, Report R10-TB-46. 98 pages. 
Harper, J. R., W. C. Austin, M. M. Morris, P. D. Reimer, and R. Reitmeier. 1994. Ecological Classification of Gwaii Haanas - Biophysical Inventory of Coastal Resources. Report prepared for Parks Canada, Calgary, Alberta by Coastal \& Ocean Resources Ltd., Sidney, British Columbia. 115 pages.

Howes, D., J. R. Harper, and E. Owens. 1994. B.C. physical shore-zone mapping system. British Columbia Resource Inventory Committee Publication 8. 71 pages.

\section{Literature Cited}

Arup, U. 1992. Caloplaca marina and C. rosei, two difficult species in North America. Bryologist 95: 148-160.

Brodo, I. M. 1973. The lichen genus Coccotrema in North America. Bryologist 76: 260-270.

Brodo, I. M. 1976. Lichenes Candenses Exsiccati: Fascicle II. Bryologist 79: 385-405.

Brodo, I. M. 1984. Lichenes Canadenses Exsiccati: Fascicle III. Bryologist 87: 97-111.

Brodo, I. M. 1988. Studies of the lichen genus Ochrolechia. 1. A new classification for Pertusaria subplicans and $P$. rhodoleuca. Canadian Journal of Botany 66: 1264-1269.

Brodo, I. M. 1992. Phytogeographic notes on the lichens of the Queen Charlotte Islands, British Columbia, Canada. Pages 86-87 in Second International Lichenological Symposium, IAL2, Abstracts. Edited by I. Kärnefelt. Lund, Sweden.

Brodo, I. M. 1995. Lichens and lichenicolous fungi of the Queen Charlotte Islands, British Columbia, Canada. 1. Introduction and new records for B.C., Canada and North America. Mycotaxon 56: 135-173.

Brodo, I. M. 2004. A new saxicolous Porina (Ascomycota, Porinaceae) from maritime rocks of Haida Gwaii (Queen Charlotte Islands), British Columbia, Canada. Pages 43-48 in Contributions to Lichenology. Festschrift in Honour of Hannes Hertel. Edited by P. Döbbeler and G. Rambold. Bibliotheca Lichenologica 88.

Brodo, I. M., and R. Santesson. 1997. Lichens of the Queen Charlotte Islands, British Columbia, Canada. 3. Marine species of Verrucaria (Verrucariaceae, Ascomycotina). Journal of the Hattori Botanical Laboratory 82: 27-37.

Brodo, I. M., S. D. Sharnoff, and S. Sharnoff. 2001. Lichens of North America. Yale University Press, New Haven, Connecticut.

Brodo, I. M., and V. Wirth. 1998. The lichens and lichenicolous fungi of the Queen Charlotte Islands, British Columbia, Canada. 4. The genus Fuscidea (Fuscideaceae). Pages 149-161 in Lichenographia Thomsoniana:. North American Lichenology in Honor of John W. Thomson. Edited by M. G. Glenn, R. C. Harris, R. Dirig and M. S. Cole. Mycotaxon Ltd., Ithaca, New York.

Chu, F. J., M. R. D. Seaward, and I. J. Hodgkiss. 2000. Effects of wave exposure and aspect on Hong Kong supralittoral lichens. Lichenologist 32: 155-170.

Clague, J. J. 1989. Quaternary geology of the Queen Charlotte Islands. Pages 65-74 in The outer shores. Edited by G. G. E. Scudder and N. Gessler. Queen Charlotte Islands Museum Press, Skidegate, British Columbia.

Degelius, G. 1974. The lichen genus Collema with special reference to the extra-european species. Symbolae Botanicae Upsalienses 20(2): 1-215.

Degelius, G. 1979. Studies in the lichen family Collemataceae. IV. Collema fecundum, a new species from North America. Botaniser Notiser 132: 569-572.
Eliasson, Y. 1965. Outline of the most common and conspicuous marine lichens on the west coast of Sweden. Botanica Gothoburgensis 3: 75-76.

Fletcher, A. 1973a. The ecology of marine (littoral) lichens on some rocky shores of Angelesey. Lichenologist 5: 368400.

Fletcher, A. 1973b. The ecology of maritime (supralittoral) lichens on some rocky shores of Anglesey. Lichenologist 5: 401-422.

Fletcher, A. 1980. Marine and maritime lichens of rocky shores: their ecology, physiology and biological interactions. Pages 789-842 in The Shore Environment. Volume 2: Ecosystems. Edited by J. H. Price, D. E. G. Irvine and W. F. Farnham. The Systematics Association Special Volume 17a, Academic Press, London.

Fletcher, A., and R. Crump. 2002. Monitoring maritime habitats. Pages 255-266 in Monitoring with lichens monitoring lichens. Edited by P. L. Nimis, C. Scheidegger and P. A. Wolseley, Kluwer Academic Publishers, Dordrecht, Netherlands.

Fryday, A. M. 2002. A revision of the species of the Rhizocarpon hochstetteri group occurring in the British Isles. Lichenologist 34: 451-477.

Gowan, S. P. 1989. The lichen genus Porpidia (Porpidiaceae) in North America. Bryologist 92: 25-59.

Heusser, C. J. 1989. North Pacific Coastal refugia - the Queen Charlotte Islands in perspective. Page 91-106 in The outer shores. Edited by G. G. E. Scudder and N. Gessler. Queen Charlotte Islands Museum Press, Skidegate, British Columbia.

Hunter, M. L., and S. L. Webb. 2002. Enlisting taxonomists to survey poorly known taxa for biodiversity conservation: a lichen case study. Conservation Biology 16: 660-665.

Jørgensen, P. M. 1978. The lichen family Pannariaceae in Europe. Opera Botanica 45: 1-123.

Jørgensen, P. M. 2000. Survey of the lichen family Pannariaceae on the American continent, north of Mexico. Bryologist 103: 670-704.

Lallemant, R., and C. Van Haluwyn. 1981. Effects des hydrocarbures sur les peuplements lichéniques marins et phénomènes de recolonisation. In Amoco Cadiz, Conséquences d'une pollution accidentelle par les hydrocarbures. Actes du Colloque International, Centre Océanique de Bretagne, Brest (France) 19-22 novembre 1979. Centre National pour l'Exploitation des Océans, Paris. 881 pages.

Lewis, J. R. 1961. The littoral zone on rocky shores - a biological or physical entity. Oikos 12: 280-301.

Little, C., and J. A. Kitching. 1996. The biology of rocky shores. Oxford University Press, Oxford. 240 pages.

Nimis, P. L., C. Scheidegger, and P. A. Wolseley. Editors. 2002. Monitoring with lichens - lichen monitoring. NATO Science Series IV, Earth and Environmental Sciences 7. Kluwer Academic Publishers, Dordrecht, Netherlands.

Noble, W. 1982. The lichens of the coastal Douglas-fir dry subzone of British Columbia. Ph.D. thesis, University of British Columbia, Vancouver.

Oberhollenzer, H., and V. Wirth. 1984. Beiträge zur Revision der Flechtengattung Fuscidea. Beiheft zur Nova Hedwigia 79: 537-595.

O'Clair, R. M., S. C. Lindstrom, and I. M. Brodo. 1996. Southeast Alaska's Rocky Shores. Seaweeds and Lichens. Plant Press, Auke Bay, Alaska. 149 pages.

Persson, H. 1968. Bryophytes from the Aleutian Islands, Alaska, collected mainly by Hansford T. Shacklette. Svensk Botanisk Tidskrift 62: 369-387. 
Ramkaer, K. 1977. The influence of salinity on the establishing phase of rocky shore lichens. Botanisk Tidskrift 72: 119-123.

Ryan, B. D. 1988a. Marine and maritime lichens on serpentine rock on Fildago Island, Washington. Bryologist 91: 186-190.

Ryan, B. D. 1988b. Zonation of lichens on a rocky seashore on Fildago Island, Washington. Bryologist 91: 167-180.

Schofield, W. B. 1984. Bryogeography of the Pacific Coast of North America. Journal of the Hattori Botanical Laboratory 55 : 35-43.

Schofield, W. B. 1989. Structure and affinities of the bryoflora of the Queen Charlotte Islands. Pages 109-119 in The outer shores. Edited by G. G. E. Scudder and N. Gessler. Queen Charlotte Islands Museum Press, Skidegate, British Columbia.

Searing, G. G., H. R. Frith, and D. Howes. 1995. B.C. biological shore-zone mapping system. British Columbia Resource Inventory Committee Publication 9: 1-46.

Sheard, J. W. 1968. The zonation of lichens on three rocky shores of Inishowen, Co. Donegal. Proceedings of the Royal Irish Academy 66, Section B: 101-112, plate VI.

Sheard, J. W., and B. W. Ferry. 1967. The lichen flora of the Isle of May. Transactions of the Botanical Society of Ediburgh 40: 268-282.
Sloan, N. A., and P. M. Bartier. 2000. Living marine legacy of Gwaii Haanas I: Marine plant baseline to 1999 and plant-related management issues. Parks Canada Technical Reports in Ecosystem Science 27: 1-104.

Southward, A. J. 1958. The zonation of plants and animals on rocky sea shores. Biological Review 33: 137-177.

Stephenson, T. A., and A. Stephenson. 1949. The universal features of zonation between tide marks on rocky coasts. Journal of Ecology 37: 289-305.

Sutherland Brown, A., and C. J. Yorath. 1989. Geology and non-renewable resources of the Queen Charlotte Islands. Pages 3-26 in The outer shores. Edited by G. G. E. Scudder and N. Gessler. Queen Charlotte Islands Museum Press, Skidegate, British Columbia.

Taylor, R. M. 1982. Marine flora and fauna of the northeastern United States. Lichens (Ascomycetes) of the intertidal region. National Oceanic and Atmospheric Administration Technical Report, National Marine Fisheries Service Circular 446. Department of Commerce, Washington, D.C.

Zacharias, M. A., and J. C. Roff. 2001. Explanations of patterns of intertidal diversity at regional scales. Journal of Biogeography 28: 1-13.

Received 30 June 2003

Accepted 17 February 2004 


\section{Appendix: Lichens of Haida Gwaii Found on Maritime Rocks}

Note: Many of the lichens listed below are non-maritime lichens that, on occasion, are found growing in the maritime zone thereby demonstrating a tolerance for salt spray. Species not found in Gwaii Haanas National Park Reserve are marked with an asterisk (*). Those new to British Columbia are in boldface. Voucher specimens of all these records can be found in the Canadian Museum of Nature (CANL).

Adelolecia koalensis (Nyl.) Hertel \& Rambold (Syn. Lecidea conferenda Nyl.) This was first reported for British Columbia in Brodo (1995).

*Amandinea coniops (Wahlenb. in Ach.) M. Choisy ex Scheid. \& H. Mayrh.

Arthonia phaeobaea (Norman) Norman

Aspicilia caesiocinerea (Nyl. ex Malbr.) Arn.

*Aspicilia supertegens Arn. This is not normally a maritime species. The single voucher specimen requires further study.

*Bacidina inundata (Fr.) Vězda. This species was also found in streams in Haida Gwaii.

* Caloplaca chlorina (Flotow) H. Olivier. The voucher specimen was verified by both T. Tønsberg and C. M. Wetmore.

Caloplaca citrina (Hoffm.) Th. Fr.

Caloplaca flavogranulosa Arup

* Caloplaca inconspecta Arup

Caloplaca litoricola Brodo

Caloplaca rosei Hasse

Caloplaca verruculifera (Vainio) Zahlbr.

* Catillaria chalybeia (Borrer) Massal.

*Cliostomum griffithii (Sm.) Coppins

Coccotrema maritimum Brodo

Collema fecundum Degel.

*Ephebe lanata (L.) Vainio

*Fuscidea mollis (Wahlenb.) V. Wirth \& Vĕzda. The voucher specimen is not typical of the species, so this record is questionable.

Fuscidea thomsonii Brodo \& V. Wirth

Fuscopannaria maritima (P. M. Jørg.) P. M. Jørg.

Gyalecta jenensis (Batsch) Zahlbr.

Herteliana alaskensis (Nyl.) Zahlbr.

* Kohlmeyera complicatula (Nyl.) Schatz

Lecanora muralis (Schreber) Rabenh.

*Lecanora poliophaea (Wahlenb.in Ach.) Ach. s. lat.

Lecanora straminea Wahlenb. ex Ach.

*Lecanora tenera (Nyl.) Cromb.

Lecanora sp. number 1 . This is a xanthone-containing, maritime, saxicolous member of the Lecanora dispersa group and almost certainly is undescribed.

Lecanora sp. number 5. This lichen is similar in many respects with L. contractula Nyl.

* Lecidella scabra (Taylor) Hertel \& Leuckert

Lecidella stigmatea (Ach.) Hertel \& Leuckert f. stigmatea

Ochrolechia subplicans (Nyl.) Brodo subsp. hultenii (Erichs.) Brodo

Opegrapha gyrocarpa Flotow

Opegrapha sp. This is a sorediate species containing roccellic acid, with 3-septate spores and lirelliform ascomata unlike those of $O$. gyrocarpa. It may be undescribed.

Parmelia saxatilis (L.) Ach.
Physcia caesia (Hoffm.) Fürnr.

Placopsis lambii Hertel \& Wirth. There is a single record of P. gelida (L.) Lindsay s. str. on a rock in a tidal marsh, but otherwise the species is only known on Haida Gwaii from inland localities, usually on roadsides and fresh rock exposures.

*Polychidium muscicola (Sw.) S. F. Gray

Porina pacifica Brodo. This species, which superficially resembles $P$. chlorotica (Ach.) Müll. Arg., was only recently described (Brodo 2004)

Porpidia carlottiana Gowan

Porpidia contraponenda (Arnold) Knoph \& Hertel

Porpidia speirea (Ach.) Kremp.

Porpidia thomsonii Gowan

*Punctelia stictica (Duby) Krog

Pyrenocollema halodytes (Nyl.) R. C. Harris s. lat. We have included specimens with sunken perithecia as well as those with sessile perithecia under this name if the perithecia were under $0.3 \mathrm{~mm}$ in diameter. The much larger $P$. sublitorale (Leighton) R. C. Harris ex Fletcher in Coppins, P. James \& D. Hawksw. has not yet been found in Haida Gwaii.

Rhizocarpon geminatum Körber

Rhizocarpon "haidensis" Brodo, ined. This species is closely related to $R$. cinereovirens (Müll. Arg.) Vainio (Fryday 2002). Its description is being prepared for publication.

* Rhizocarpon hensseniae Brodo

Rhizocarpon hochstetteri (Körber) Vainio s. str. A detailed discussion of this species is provided by Fryday (2002).

*Rinodina gennarii Bagl.

Spilonema revertens Nyl.

*Tephromela atra (Hudson) Hafellner in Kalb

*Tylothallia biformigera P. James \& R. Kilias in R. Kilias

Verrucaria amphibia Clemente

Verrucaria degelii R. Sant.

Verrucaria epimaura Brodo

Verrucaria erichsenii Zsch.

*Verrucaria halizoa Leighton

Verrucaria maura Wahlenb. in Ach.

Verrucaria mucosa Wahlenb. in Ach.

Verrucaria sandstedei de Lesd. This species, like V. striatula listed below, was reported from coastal rocks in Fildago Island, Washington, by Ryan (1988a, b).

Verrucaria schofieldii Brodo

*Verrucaria silicicola Fink

Verrucaria striatula Wahlenb. See comment under V. sandstedei.

Verrucaria sp. number 5 (dry rock at edge of beach)

Xanthoria candelaria (L.) Th. Fr. 


\section{Errata for The Canadian Field Naturalist 118(3)}

Inside front cover bottom:

Cover. Intertidal zone on rugged rock headland of the Queen Charlotte Islands, British Columbia. Each dominant species creates a distinct zone. The white lichen is mainly Coccotrema maritimum and the black one is almost entirely Verrucaria maura. Below the Verrucaria is a zone bare of both lichens and marine algae, and, still lower, the algae take over. This caption and photo (the latter in colour) have previously appeared as Figure 64, page 77, in Lichens of North America by I. M. Brodo, S. D. Sharnoff, and S. Sharnoff. 2001. Yale University Press, New Haven Connecticut. See article by Brodo and Sloan on lichen zonation, pages 405-424.

On page 408, Figure 2, the islands were omitted.

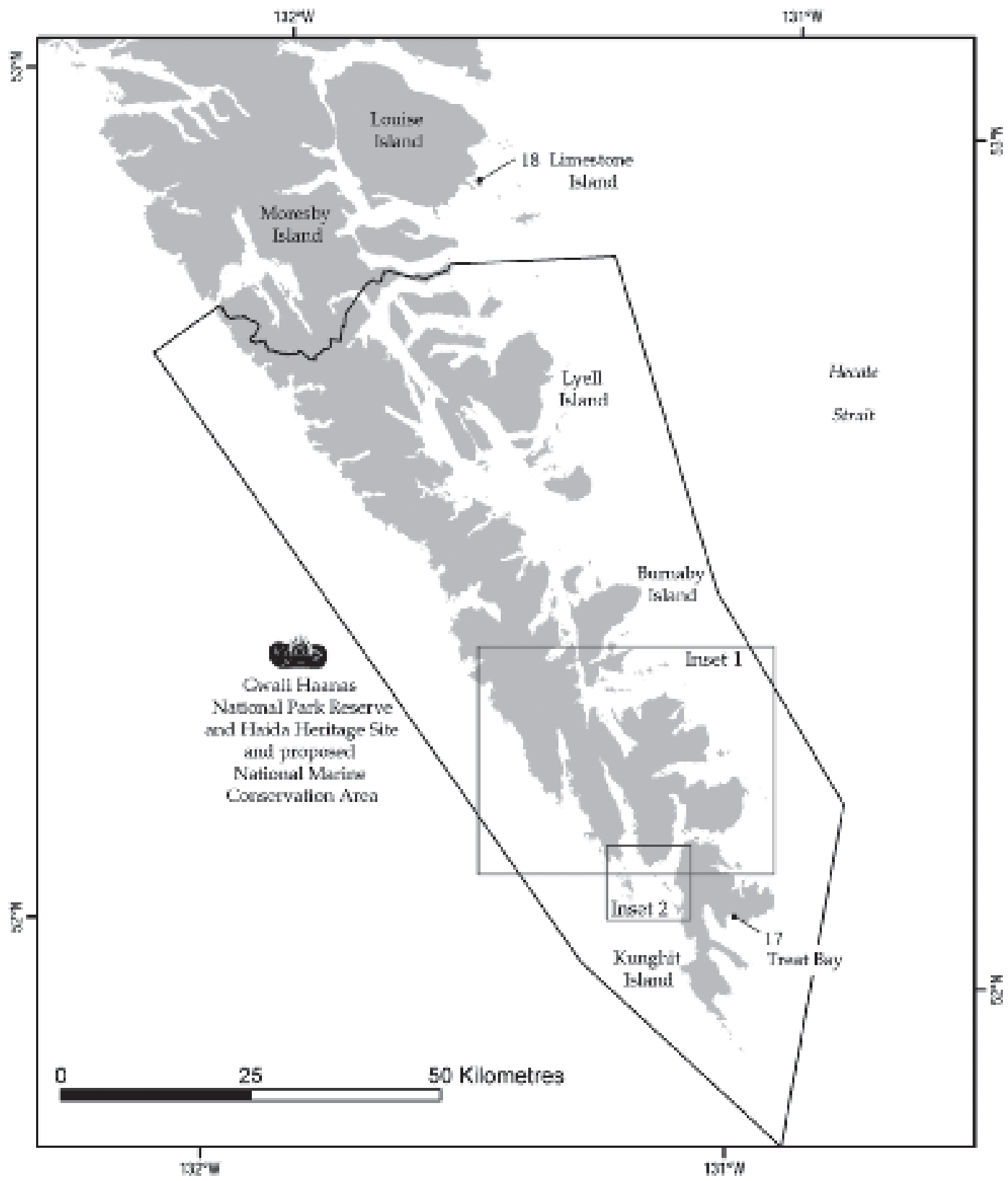

FiguRE 2. Map of the Gwaii Haanas area showing Limestone Island (location 18) to the north and Treat Bay (location 17) to the south of the insets. 